\title{
A Strategic Model for Issues Management Communication: How To Respond To AcCusations of Unethical Corporate Behavior
}

\author{
Dennis E. Garrett \\ Jeffery L. Bradford \\ Renee A. Meyers \\ University of Oklahoma \\ Norman, Oklahoma
}

The telephone call you receive upon arriving at your office on a Monday morning is from an Associated Press reporter. The reporter opens the conversation by saying, "I have just received a call from the Alliance for Corporate Responsibility, and they have accused your company of engaging in business practices that are unethical and harmful to customets. What is your response to these accusations?"

This is clearly a delicate situation. From prior experience, you know that the Alliance is a powerful group that is adept at using the media to its advantage. You also know that the response you give to this reporter will undoubtedly appear in many major newspapers. If the newspapers' readers, many of whom are considered by your company's management to be key constituents, find your response to be appropriate given the nature of the accusation, your company will probably be able to minimize the impact of the Alliance's protest action. However, if your response is inappropriate, many readers may question your company's motives and sympathize with the Alliance's goals. Additionally, an inappropriate response may fuel the $\mathrm{Al}$ liance's cause, generate additional media inquiries and coverage, and severely damage your company's public image and sales. Certainly, your response to this is critically important. What do you say?

This is the type of situation which corporate executives would prefer to avoid. However, recent evidence suggests that external protest groups are increasing this pressure on corporations in a variety of public areas ([7], [8], [10], [11]). As a result, executives find that increasingly they must be prepared to respond to accusations of improper corporate behavior raised by external protest groups.

In recent years the research domain of "Issues Management" has sought to analyze and understand such contentious situations ([3], [4], [14], [24]). Issues management research investigates how corporations can most effectively identify and respond to environmental developments that present opportunities of threats to corporate welfare ([1], [27]). Communication plays a central strategic role in the issues management process, especially in situations where an organization is accused of unethical behavior $([6],[13],[14])$. The type of communicative response offered by managers significantly

Journal of Business Strategies, Volume 6, Number 2 (Fall 1989) 
influences the evolution of conflict with the accusing group, the perceptions of the outside viewers, and the media coverage. Effective communication strategies are essential for blunting the potential negative impact of the accusations, for advocating the organizations' position, and for preserving the corporation's positive public image.

Even though the importance of managerial communication to the issues management process is widely accepted, little research has focused on the developing a strategic model for issues management communication. Previous research has tended to present list of possible communicative responses without fully specifying when and why particular strategies should be used $([17],[22],[23],[26])$. Lacking strong theoretical underpinnings, these models are unable to neither provide guidelines for analysis of accusations by protest groups, nor suggest communication strategies appropriate for mitigating such indictments.

In this paper we propose a strategic model for issues management communication that focuses specifically upon situations in which a corporation is accused of unethical organizational behavior. First, we briefly review recent theoretical work on impression management [18], and utilize that perspective as a framework for grounding our model of strategic communication. Second, we present a model of issues management communication that incorporates three stages of analysis: (1) Evaluation of Commission, (2) Assessment of Responsibility, and (3) Review of Evaluation Standards. Third, we utilize examples of actual communication strategies used by managers whose organizations were recently accused of unethical behavior to more fully explicate and validate our proposed model. Finally, we will discuss the strategic implications of our model for issues management.

\section{Theoretical Framework}

To frame our issues management communication model, we draw upon recent theoretical work in the research domain of Impression Management. Impression management theory suggests that social actors must continually analyze and adjust their communication so that other actors form favorable impressions of them ([9], [12], [18]). Impression management is especially important in situations where an actor has been accused of wrongdoing, has performed an irresponsible act, or has made a public mistake. Such predicaments call for the actor to provide an "account" of his/her behavior that will mitigate forthcoming adverse consequences. Within the impression management framework, accounts are defined as communication strategies designed to minimize negative repercussions that may accrue when an actor is accused of improper behavior ([5], [18]). Previous research on accounting behavior of individuals accused of wrongdoing indicates that accounts fall into four basic categories: denials, excuses, justifications, and concessions $([5],[18],[20])$. Further, research has suggested that the the type of account offered by an accused actor affects the resolution of conflict with the accusing actor ([5], [21]) and the judgments made by other parties concerning the legitimacy of the accusations ([2], [18]).

Impression management theory and its analysis of accounts provides an excellent theoretical basis for development of a strategic model for issues management communication. Yet, we think previous impression management research is limited in two 
respects, each of which we address in this paper. First, most previous impression management research on accounts has focused on the interpersonal context, investjgating individuals who have been accused of improper personal behavior, rather than managers whose corporations have been accused of unethical organizational behavior. Second, even though impression management research has established the four categories of accounts (denial, excuses, justifications, and concessions), we extend that finding by proposing a strategic model for managerial use that explains how the choice among these four communication strategies should be made. In so doing, we think our proposed model promises to provide a more complete description of the strategy selection process, and allows more effective selection of appropriate communication strategies for given issues management situations.

\section{Proposed Model}

As indicated earlier, previous discussions of strategic communication in the issues management process have tended to focus on the lists of strategies without providing a systematic and coherent foundation for building a manager's choice of an appropriate response $([17],[22],[23],[26])$. In this section we propose a strategic model based on impression management theory which (a) identifies the steps a manager should follow in analyzing the accusations of protest groups, and (b) indicates which communication strategies are most appropriate given the outcome of this analysis process. More, specifically, as shown in Figure 1, our model posits that managers should progress through three stages of analysis: (1) Evaluation of Commission, (2) Assessment of Responsibility, and (3) Review of Evaluation Standards. This three-stage analytical process then guides the manager's choice of the most effective and appropriate communication strategies, which include (a) denials, (b) excuses, (c) justifications, or (d) concessions.

In the next section, we employ actual communication strategies used by corporate managers who faced accusations of unethical organizational practices to demonstrate the practicality of the model. Prior to that exposition, we briefly describe the survey methodology used to obtain these managerial communication strategies.

\section{Survey Methodology}

The examples we utilize to explicate the model emanate from a larger study of consumer boycotts. Because consumer boycotts represent an important, widespread, and increasingly occurrent issues management situation and moreover, because they typically generate public debate $([10],[11],[15])$, they provide an excellent base from which to validate a model of strategic issues management communication.

Consumer boycotts were identified by careful examination of sixteen newspaper and periodical indices which represented a broad cross-section of national and regional sources for boycott activity. This review yielded a total of 30 identifiable and conformed boycotts. Telephone interviews were conducted with the person in each of the 30 boycott organizations most qualified to respond to inquires regarding the 
Figure 1

A Strategic Model for Issues Managment Communication

\begin{tabular}{|c|c|c|}
\hline $\begin{array}{l}\text { Evaluation of } \\
\text { Commission }\end{array}$ & $\begin{array}{l}\text { Assessment of } \\
\text { Responsibility }\end{array}$ & $\begin{array}{l}\text { Review of Evaluative } \\
\text { Standards }\end{array}$ \\
\hline $\begin{array}{l}\text { Did we commit } \\
\text { this act? }\end{array}$ & $\begin{array}{l}\text { Are we responsible } \\
\text { for this act? }\end{array}$ & $\begin{array}{l}\text { Do we agree with the } \\
\text { standards of evaluation? }\end{array}$ \\
\hline Yes & No & $\begin{array}{l}\rightarrow \text { Yes } \\
\text { Concessions } \\
\rightarrow \text { No }\end{array}$ \\
\hline Denials & $\begin{array}{l}\text { Excuses } \\
\text { a) legal constrainst } \\
\text { b) financial conditions }\end{array}$ & $\begin{array}{l}\text { Justifications } \\
\text { a) higher royalties } \\
\text { b) avoidance of greater harm } \\
\text { c) competitive standards } \\
\text { d) legal right } \\
\text { e) malicious intentions of accusers }\end{array}$ \\
\hline
\end{tabular}

dispute [25]. Although using multiple respondents from an organization has certain benefits [16], only one respondent per organization was used because in most organizations only one person was adequately informed or authorized to answer these questions. To encourage respondent cooperation and candor, the respondents were guaranteed anonymity.

Communication strategies were solicited by asking the respondents a set of openended questions regarding their organizations' perceptions of the protest groups' accusations of allegedly unethical organizational policies. Interviews were completed with respondents from 23 of the 30 eligible organizations ( $77 \%$ completion rate). The most common reason for non-response was lack of time complete the interview. The managers' responses are utilized in the next section to clarify and validate the proposed strategic model. Following presentation of these examples, the advantages and disadvantages of the communication strategies are outlined.

\section{Explication of Model and Examples}

\section{Stage One: Evaluation of Commission}

The first logical stage in the issues management communication process is to evaluate whether the accusations leveled by the protesters are valid. The manger must ask "Did we actually commit the act we are accused off committing?" Surprisingly, in some cases the protesters receive erroneous information and incorrectly accuse a company of using a certain harmful policy. The manager's first take is to carefully understand the exact nature of the protesters' complaint. After the complaint is fully 
understood, the manager should contact the necessary personnel in the company who are most closely associated with these allegedly harmful policies or practices to determine if the company is really doing what the protesters are claiming. If this information check shows that the company is not involved in these disputed policies, the most appropriate communications strategy is a strong and emphatic Denial. For example, in one dispute the protesters accused a fast food chain of using veal that is raised under alleged inhumane conditions. Having determined that the organization did not commit this act, the restaurant manager denied the charge:

The group accused us of using a special veal that is bred under special conditions and which is very expensive. But we were actually using rangefed veal which is not bred under these supposedly inhumane conditions. end quote

Another interesting example of a denial occurring when a protest group accused a major nonprofit organization of being involved in abortion-related programs. The director of the nonprofit organization argued that the accusation was unfounded and that the organization had not committed any wrongdoing:

There was a misunderstanding of what we were going to do. This program was only in the draft proposal stage, but erroneous information got out.... This group rescinded their remarks after we explained the situation to them.

The major advantage to a denial is that it offers the greatest potential protection for the accused company and may quickly put an end to the issue. However, managers in accused companies must be careful not to offer a denial if there is any chance that the protesters' allegations may be true. If a denial is made then information emerges that the company was in fact involved in the disputed policy area, the company's credibility may be severely damaged and it may appear that the company was trying to "cover up" the truth. Therefore, a denial should be used only when the facts conclusively show that the protesters have incorrectly accused the company. If the manager determines that his/her company is or was involved in the disputed policy area the protesters claim, then the manager should move to the model's second stage, Assessment of Responsibility.

\section{Stage Two: Assessment of Responsibility}

The major task at this second stage is to determine the level of responsibility that the accused organization should accept for any negative consequences that accrue from its involvement in the disputed policy areas. The assessment of responsibility is directly related to the amount of control the organization has over the policy area that is repugnant to the protesters. 
Managers may determine that their organization either (a) lack complete control over policy options because of certain constraints, or (b) have freedom to exercise complete control over policy options.

If managers conclude that their organization lacks complete control over policy options, and therefore cannot make the changes demanded by the protesters, the most appropriate communication strategy to be employed is the Excuse. Excuses are used to argue that, due to a lack of control over policy options, the organization should not be held responsible for any negative outcomes from its policies.

Two major categories of excuses, legal constraints and financial conditions, are often applicable when organizations are accused of engaging in unethical behavior. Legal constraint excuses argue that the organization's control over policy options is limited by certain legal or governmental regulations. For example, a major manufacturing company was accused of using a potentially-harmful chemical in its production processes. The manager responded by offering a legal constraint excuse:

This was the only herbicide approved for use in Nova Scotia by the government.... Our hands were tied. We had to spray and the only thing available to spray was this product.

Financial conditions excuses, on the other hand, are used to argue that economic factors constrain the policy alternatives available to the accused organization. This type of excuse contends that the policy changes advocated by the protesters are unreasonable because the organization could not possibly afford to meet the protesters' demands. The manager argues that the overwhelming financial burden created by the protesters' proposed changes limits the organization's degree of control and responsibility in this dispute. For example, a group advocating greater rights for the handicapped pressed a major hotel chain to extensively modify its rooms to make them more accessible for the handicapped. The hotel chain executive responded with a financial condition excuse:

They wanted us to change the widths of the doorways to the bathrooms.... This is not easy to do because you would have to relocate also the electrical systems.... These modifications would have been expensive.

The major advantage of excuses is they allow a manager to demonstrate his/her organization's innocence because of a lack of control in the contentious policy area. If the organization absolutely cannot make the policy modifications demanded by the protesters because of legal or financial constraints, then an excuse helps to protect the organization's public image from the negative repercussions of the conflict. It seems especially likely 
that legal constraint excuses will be perceived as credible because key constituents are apt to believe that organizations, even major corporations, are limited by the law in certain policy areas. If managers who choose to use a legal constraint excuse are careful to thoroughly document their position with ample explanation of legal regulations, the legal constraint excuse may be especially powerful.

However, the excuses may also carry a certain amount of risk, especially the financial conditions excuse. Many key constituents assume that organizations, especially major corporations, have an unlimited financial capacity to institute policy changes. Therefore, if a manager argues that his/her corporation is unable to make the changes because of the expense involved, many constituents are likely to view this excuse as unacceptable. They may even believe that the organization's use of this financial conditions excuse is further evidence of the accused organization's preoccupation with money and its insensitivity to the protesters' concerns. In sum, both the advan. tages and disadvantages of excuses must be weighed very carefully before utilization.

Finally, if a manager determines that his/her organization's policy options are not constrained, and excuses are therefore inappropriate, then the analysis should progress to the third stage of out model, Review of Evaluative Standards.

\section{Stage Three: Review of Evaluative Standards}

In the final analysis stage, managers who determine that their organizations have control over policy options must ask whether the evaluative standards employed by the group are appropriate. Protesters often use a certain evaluative standard in their accusations that differ dramatically from the standard for behavior adopted by the accused organization. As a result, the impetus for the dispute is the protesters' belief that the target organization's policies do not meet an acceptable standard of organizational behavior.

At this third stage of analysis, a manager must analyze the standards that the protesters are using to evaluate his/her organization's policies, as well as the standards the organization used in adopting its disputed policies. This analysis may yield two potential outcomes: (a) the manager concludes that the protesters' standards are not appropriate and that instead the organization's standards are more appropriate criteria, or (b) the manager concludes that the accuser's standards are legitimate. In the first case, when the manager determines that the protester's evaluative standards are faulty and the other standards demonstrate the merit of the organization's policies, the most appropriate communication strategy a manager can offer is a Justification. Justifications suggest that, even though the organization 
is fully responsible for the disputed policies, certain factors support the legitimacy of these policies and diminish the negative implications of the accusations.

At least five types of justifications may be used by managers in accused organizations: (a) higher loyalties, (b) avoidance of greater harm, (c) comparative standards, (d) legal right, and (e) malicious intentions of accusers. The first justification, higher loyalties, asserts that the disputed policy is acceptable because the organization is pursuing goals so important that they offset any negative consequences of the disputed policies. For example, when protesters tried to force a major military weapons manufacturer to stop the production of nuclear components, the manager responded with a higher loyal ties justification based on the government's expressed need for higher national security:

We agree with the objectives of peace and arms control, but the government policy has determined the need for production of military equipment.... We have decided that we will participate selectively in the production of this equipment.

The second type of justification, avoidance of greater harm, allows the manager to argue that greater damage would be created if the organization actually made the policy changes demanded by the protesters. Because greater harm would be created, this justification suggests that the evaluative standards used by the protesters are seriously flawed and their accusations unfounded. For example, a manager of a leading drug company used this type of justification to argue against the protesters' demands that his company should remove a particular drug from the market:

(This drug) revolutionized the treatment of mental health.... This was a revolutionary drug which had beneficial effects.... The side effects of the drug are no secret. They are listed in the Physicians' Reference.

Comparative standards is the third type of justification which may be employed by managers as a communication strategy. With this justification, a manager compares his/her organization's record in the disputed policy area with other similar organizations which have not been singled out and accused of unethical behavior by the protesters. By demonstrating that his/her organization is consistent with or superior to the norms of other unaccused organizations, the manager seeks to show that the protesters' specific accusations against his/her organization are capricious and unfounded. When protesters accused a major food chain of discriminatory hiring practices, the manager responded with a comparative standards justification: 
The first thing we wondered is 'Why have we been singled out?'....

Our statistics showed we were better than the national average in this area.

The fourth justification, legal right, bears a strong resemblance to the legal constraint excuse discussed earlier. However, whereas a legal constraint excuse suggests that an organization cannot make the protesters' desired changes due to legal restrictions, a legal right justification argues that the organization's disputed policy is legally acceptable. Thus, the legal right justification indicates that, even though the organization could legally make the demanded changes, the organization is not legally required to do so. Because the law does not mandate the changes demanded by the protesters, a manager could argue that his/her organization's allegedly harmful policies are appropriate. For example, when protesters challenged a bank's rewriting of mortgages at a higher interest rate, the manager responded with a legal right justification:

We had a legal right to rewrite these mortgages at the higher rate.

The fifth justification, malicious intentions of accusers, focuses on the motives of the protesters in the dispute. By using this justification, a manager hopes to demonstrate that, while his/her organization's allegedly improper actions are actually based on acceptable standards of conduct, the accusers are malicious and devious. A manager may use this justification to cause key constituents to question the character of the accusers and the validity of their accusations, For example, a manager in a bank accused of unfair lending practices used this justification:

(The protesters) do not want to deal with the issues. They are not serious about helping unemployed workers. This is socialistic and they are trying to undermine the free market system. They know it and they don't give a damn!

The effectiveness of justifications depends on two factors: (a) key constituents' perception of the comparative credibility of the accused organization to that of the protesting group, and (b) the value structures of key constituents. First, one factor that key constituents will use to evaluate the acceptability of justifications is the comparative credibility of the accused organization and the protesting group. Justifications are likely to be more persuasive if the accused organization has a history of socially responsible behavior and the protesters have a history of making unfounded accusations solely to generate media coverage. In contrast, if the accused organization has repeatedly been found "guilty" of socially irresponsible behavior and been unwilling to correct past problems, and the protesters have a history 
of uncovering and proving gross organizational abuses, justifications are likely to be less influential.

Second, justifications may not be equally persuasive to all groups of constituents because they possess varying value structures. A manager may have to offer several types of justifications to persuade different groups of constituents. For example, a legal right justification may be most persuasive to governmental regulators, an avoidance of greater harm justification may be most acceptable to consumers, and a malicious intentions of accusers justification may be most credible to distributors and suppliers.

In addition, the use of justifications is not without certain risks, particularly when the legal right justification or the malicious intentions of the accusers justification is utilized. In the first case, the distinction between legal acceptability and moral appropriateness has always been open to debate. As many issues managers have concluded from their own experience, just because an organizational policy is legally accepted does not automatically mean that it is beyond reproach. A legal right justification may help to blunt the negative consequences of an accusation, but a manager should also be prepared to defend the contentious policy on moral grounds. To establish this moral appropriateness argument, a manager may choose to use an avoidance of greater harm justification and suggest that any change from the disputed policy would only generate more damage and therefore be an immoral action.

In heated conflicts many managers are inclined to vent their frustration with the protesters by offering justifications focusing on the malicious intentions of the accusers. This justification is especially risky because many constituents may perceive this communication strategy as a "cheap shot" used by an organization which is overly defensive and perhaps has no other rational basis for responding to these accusations. The potential for negative consequences with this justification is particularly great when key constituents perceive that the protesters' concerns are genuine and that they are not pursuing ulterior motives for their own personal gain.

Finally, as discussed earlier, in this third stage of analysis, the manager may conclude that the evaluative standards of the protesters are either inappropriate or appropriate. If she/he concludes they are inappropriate, we have demonstrated that the justification is the most suitable communication response. However, if a manager determines that the standards used by the accusers are legitimate, then a manager must consider the Concession as the most timely communication strategy. A concession indicates that (a) the organization is involved in the disputed area, (b) does have control and responsibility in this area, and (c) basically agrees with the evaluative standards used by the accusers. For example, when a group of real estate developers accused a major city newspaper of unfair coverage, the editor of 
the paper offered a concession:

They had a legitimate bitch. The editorial department was not equipped to handle the real estate section.... Management realized that we made a bad mistake.

Managers may be reluctant to offer a concession because they fear it will be perceived as a sign of organizational weakness. Further, managers may be concerned that a concession will encourage other protest groups to also confront the organization with their particular demands for policy changes. For example, a publisher of a major city newspaper, which was accused of unfair coverage of minority news, stated:

To give in to the demands of one group just attracts more trouble from other groups.

While a manager should not concede to unfounded accusations, we believe that too often managers refuse to acknowledge organizational mistakes and offer a concession as a appropriate communication response. This type of managerial intransigence is unfortunate because the prompt and sincere offering of an apology for organizational errors may be quite beneficial. Key constituents are likely to react positively to an organization which is willing to be responsive to legitimate external criticism [18]. For example, when Chrysler was accused of selling repaired cars as new to the public, Lee Iacocca received widespread praise for his frank acknowledgment of Chrysler's error and his promise that such actions would not reoccur [19]. While concessions are often the most difficult communication strategy to employ, if communicated with sincerity and tact, they can be very effective in defusing potentially harmful conflicts.

\section{Conclusion}

Communication plays a central strategic role in the issues management process, especially when an organization has been accused of unethical practices. In such circumstances, organizations cannot afford to let protesters control the communicative agenda. Managers must be prepared to respond quickly and effectively to accusations before key constituents form enduring opinions based solely upon information provided by the protest group. Prompt and effective communicative responses can only emerge if managers are familiar with and understand the strategic implications of available communication response options. This paper proposes a model for strategic issues management communication aimed at helping managers evaluate contentious situations and choose an appropriate communicative response. Framing this model within impression management theory both represents a significant advancement over previous models which have simply offered 
lists of possible communication response options, and provides managers with a firm basis from which to evaluate and choose effective communication strategies.

\section{References}

1. Ansoff, H. Igor. "Strategic Issue Management." Strategic Management Journal, Vol. 1 (1980), pp. 131-148.

2. Bradely, Gifford Weary. "Self-Serving Biases in the Arbitration Process: A Re-examination of the Fact of Fiction Question." Journal of Personality and Social Psychology, Vol. 36, No. 1 (1978), pp. 56-71.

3. Brown, James K. This Business of Issues: Coping with the Company's Environments. New York, NY: The Conference Board Inc. (1979).

4. Chase, W. Howard. Issue Management: Origins of the Future. Stamford, CT: Issue Action Publication (1984).

5. Cody, Michael J. and Margaret L. McLaughlin. "Models for the Sequential Construction of Accounting Episodes: Situational and Interactional Constraints on Message Selection and Evaluation." In R. L. Street Jr. and J. N. Capella (eds.), Sequence and Pattern in Communicative Behavior, Baltimore, MD: Edward Arnold (1985), pp. 50-69.

6. Crable, Richard E. and Stephen L. Vibbert. "Managing Issues and Influencing Public Policy." Public Relations Review, Vol. 11 (Summer 1985), pp. 3-16.

7. Friedman, Monroe. "Consumer Boycotts." Proceedings of the American Council on Consumer Interests (1982), pp. 96-97.

8. Friedman, Montoe. "Consumer Boycotts in the United States, 19701980: Contemporary Events in Historical Perspectives." Journal of Consumer Affairs, Vol. 19 (Summer 1985), pp. 96-117.

9. Gardner, William L. and Mark J. Martinko. "Impression Management: An Observational Study Linking Audience Characteristics with Verbal Self-Presentations." Academy of Management Joumal, Vol. 31, No. 1 (1988), pp. 42-65.

10. Garrett, Dennis E. "The Effectiveness of Marketing Policy Boycotts: Environmental Opposition to Marketing." Journal of Marketing, Vol.51, (April, 1987), pp. 46-57.

11. Garrett, Dennis E. "Strategic Guidelines for Responding to Consumer Boycotts." Journal of Business Strategies, Vol. 4, No. 2 (Fall 1987), pp. $48-58$.

12. Goffman, E. Relations in Public. New York, NY: Basic Books (1971). 
13. Heath, Robert L. "Corporate Advocacy: An Application of Speech Communication Perspectives and Skills and More." Communication Education, Vol. 29 (September, 1980), pp. 370-377.

14. Heath, Robert L. and Richard Alan Nelson. Issues Management: Corporate Public Policymaking in an Information Society. Beverly Hills, CA: Sage Publications (1986).

15. Meyer, Alan D. "Adapting to Environmental Jolts," Administrative Science Quarterly. Vol. 27 (1982), pp. 515-537.

16. Phillips, Lynn. "Assessing Measurement Error in Key Informant Reports: A Methodological Note on Organizational Analysis in Marketing." Journal of Marketing Research, Vol. 18, (November, 1981), pp. 395-415.

17. Ressler, Judith A. "Crisis Communications." Public Relations Quarterly, Vol. 27 (Fall 1982), pp. 8-10.

18. Schlenker, Barry R. Impressions Management: The Self-Concept, Social Identity, and Interpersonal Relations. Monterey, CA: Brooks/Cole Publishing Co. (1980).

19. Schlesinger, Jacob M. "Chrysler Finds a Way to Settle Odometer Issue." The Wall Street Journal, November 12, 1987, p. 7.

20. Schonbach, Peter. "A Category for Account Phases." European Journal of Social Psychology, Vol. 10 (1980), pp. 195-200.

21. Scott, Marvin B. and Stanford M. Lyman. "Accounts." American Sociological Review, Vol. 23 (February, 1986), pp. 46-62.

22. Sethi, S. P. "A Conceptual Framework for Environmental Analysis of Social Issues and Evaluation of Business Response Patterns." Academy of Management Review, Vol. 4, No. 1 (1979), pp. 63-74.

23. Shelby, Annette N. "A Typology of Communication Strategies for Corporate Advocacy." Journal of Business Strategies, Vol. 2, No. 1 (Spring 1985), pp. 33-38.

24. Stanley, Guy D. D. Managing External Issues: Theory and Practice. Greenwich, CT: JAI Press (1985).

25. Sudman, Seymour and Norman M. Bradburn. Asking Questions. San Francisco, CA: Jossey-Bass Publishers (1982).

26. Vitell, Scott J. and Stephen J. Grove, "Marketing Ethics and Techniques of Neutralization." Journal of Business Ethics, Vol. 6 (1987), pp. $433-438$.

27. Wartick, Stephen L. and Robert E. Rude. "Issues Management: Corporate Fad or Corporate Function?" California Management Review, Vol. 29, No. 1 (Fall 1986), pp. 124-140. 